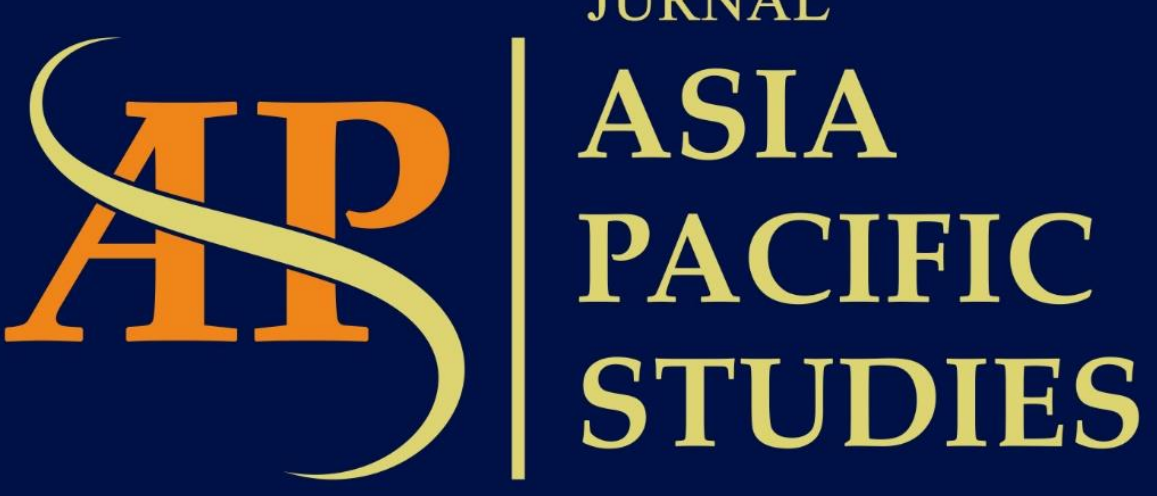

Journal of International Relations Study Program Faculty of Social and Political Sciences Universitas Kristen Indonesia

Volume I | Number 2 | July - December 2017 


\title{
TURNKEY PROJECT DAN DINAMIKA PENGATURAN KETENAGAKERJAAN ASING DI INDONESIA
}

\author{
${ }^{1}$ Suciliani Octavia, ${ }^{2}$ Muhammad Badaruddin \\ ${ }^{1,2}$ Center for Politics and Governance Studies, Universitas Bakrie, Jl. HR. Rasuna Said, Jakarta Selatan, 12940 \\ ${ }^{1}$ sucilianioctavia95@gmail.com \\ ²muhammad.badaruddin@bakrie.ac.id
}

\begin{abstract}
China's aggressiveness to conduct its belt and road initiatives through the Pacific Rim meets Presiden Joko Widodo's ambition to attract foreign investment. The Indonesian President has been very ambitious in reaching high economic growth that requires readiness of infrastructure support. In dealing with China, Indonesia is required to accept China's turnkey project scheme for infrastructure development, particularly in welcoming Chinese workers and equipments as an integral part of the project package. As a consequence, Indonesia has to loose its foreign worker regulation despite creating new contradictions with its domestic policy. This article is trying to investigate China's funding and investment influence in Indonesia particularly in the foreign worker management during the period of President Joko Widodo Administration. The research conducted with qualitative method particularly the case study to analyze a sequential case in the field. Result of this research shows that the China's turnkey project scheme impacts the foreign worker management in Indonesia. Our data displays pretty massive cases related to Chinese workers, extending from the violation of immigration regulation to the increase number of smuggling and other criminal activities. This research also highlight the indication that the Joko Widodo Administration tend to loose the Indonesian foreign worker regulations, as well as being less assertive in processing varous immigration cases which related to Chinese foreign workers. Moreover, the Jokowi administration has changed lots of regulations despite it has conflicting issues with the Law on Foreign Worker. On the other hand, the Parliament's Special Committee on the Foreign Worker Issue has recommended the Jokowi Administration to pay more serious attention on cases related to the Chinese workers.
\end{abstract}

Keywords: Turnkey Project, Foreign Investment, Foreign Aid, Regulation on Foreign Worker, Illegal Foreign Worker

\begin{abstract}
Abstrak
Agresivitas Pemerintah China dalam menjalankan belt and road initiatives ke berbagai negara yang terpetakan dalam road map-nya, bertemu dengan kepentingan Indonesia di bawah Pemerintahan Joko Widodo. Yakni ambisi untuk mengejar target pertumbuhan yang tinggi yang mempersyaratkan dibangunnya berbagai proyek infrastruktur sebagai penunjangnya. Pembangunan berbagai proyek tersebut membutuhkan ketersediaan anggaran yang cukup besar dalam waktu cepat. Salah satu strategi pemenuhannya adalah dengan mencari investasi maupun pinjaman luar negeri, terutama asal China yang secara koinsiden juga sedang agresif berekspansi. Kehadiran investasi dan pinjaman asal China di Indonesia dengan skema turnkey project ternyata menimbulkan ekses yang tidak sederhana. Skema tersebut menjadi salah satu pintu masuk tenaga kerja asal China melalui proyek-proyek infrastruktur yang ternyata menimbulkan permasalahan baru dalam pengaturan sektor ketenagakerjaan asing (TKA) di Indonesia. Irisan fenomena dari keinginan untuk merealisasikan proyek infrastruktur secara cepat, kebutuhan anggaran yang cukup tinggi terhadap pendanaan proyek dari China, dan kekurangsiapan dalam pengaturan masuknya tenaga kerja asing adalah fokus dari penelitian yang hasilnya penulis tuangkan dalam artikel ini. Dari penelitian yang dilakukan, terdapat peningkatan berbagai kasus yang terkait dengan kehadiran TKA asal China, antara lain adalah penyalahgunaan visa, penyalahgunaan status kerja, sampai pada meningkatnya angka penyelundupan dan tindak kriminalitas. Penelitian ini menggunakan metode kualitatif dengan menganalisis secara triangular beberapa data yang didapatkan melalui wawancara terhadap narasumber primer, pengolahan dokumen-dokumen resmi, analisis terhadap berbagai literatur dan pemberitaan media massa.
\end{abstract}

Kata Kunci: Turnkey Project, Investasi Asing, Pinjaman Asing, Tenaga Kerja Asing, Peraturan Ketenagakerjaan 


\section{Pendahuluan}

Pembangunan infrastruktur yang ditargetkan oleh pemerintahan Presiden Joko Widodo sebagai mana tercantum dalam RPJMP 2015-2019 adalah agenda penting dalam upaya mencapai target pertumbuhan ekonomi sebesar tujuh persen. Untuk mewujudkan pembangunan infrastruktur tersebut, pemerintah membutuhkan anggaran yang bersumber dari pendanaan dalam negeri serta investasi maupun pinjaman dari luar negeri. Sementara kemampuan Pemerintah Indonesia melalui APBN juga sangat terbatas, yakni hanya sepertiga dari nilai total proyek sebagaimana dijelaskan oleh Kepala Bappenas RI dalam Musrenbangnas pada April 2017 lalu (Katadata.co.id, 2017). Maka, sisa kebutuhan anggaran lainnya dapat dipenuhi oleh pihak swasta, investasi maupun pinjaman asing, serta lembaga keuangan regional dan multilateral seperti Asian Infrastructure Investment Bank (AIIB), dan lainnya.

Investasi maupun pinjaman asing ini dibutuhkan untuk membangun dan memperbaiki jalan di Sumatera, Kalimantan dan Sulawesi, membangun jalan tol sepanjang $2.600 \mathrm{~km}$, membangun dan memperbaiki 24 pelabuhan di Sumatera, Kalimantan, Jawa, Sulawesi, Maluku dan Papua, membangun 39 waduk baru, membangun dan memperbaiki 15 pelabuhan udara, membangun 6 Mass Rapid Transit di 6 kota besar di Indonesia termasuk Jakarta, Bandung dan Surabaya. Kemudian, adanya rencana pembangunan pembangkit listrik di berbagai daerah yang akan bertujuan untuk membantu pembangunan sektor industri di Indonesia.

Untuk merealisasikan hal tersebut, Presiden Joko Widodo tak jarang terjun langsung ke lapangan dalam usaha untuk menarik investasi maupun pinjaman dari luar negeri agar masuk ke Indonesia. Salah satunya seperti dilakukan oleh Presiden Jokowi pada event Asia-Pacific Economic Cooperation (APEC) Economic Leaders' Meeting ke 22 di Beijing pada November 2014. Dalam event itu, presiden berusaha untuk menarik investasi dari luar negeri sekaligus menjadikan dirinya sendiri sebagai penjamin yang akan membantu para investor asing dengan menyelesaikan berbagai kendala yang menjadi penghambat masuknya investasi asing selama ini.

Dengan adanya pernyataan Presiden Joko Widodo tersebut, para investor China menyambut dengan baik. Ditandai dengan jumlah rencana investasi China di Indonesia sepanjang tahun 2015 yakni sebesar Rp277,59 triliun. Kepala BKPM Franky Sibarani menjelaskan bahwa nilai pengajuan izin prinsip China sepanjang 2015 naik 67 persen dibandingkan dengan tahun sebelumnya. Hal ini menunjukkan bahwa Indonesia menjadi salah satu negara tujuan investasi utama bagi China.

Investasi yang dilakukan oleh para investor China lebih berfokus pada sektor infrastruktur dengan jumlah Rp150,89 triliun untuk sektor kelistrikan atau sebesar atau 54,36 persen dari total rencana investasi China (cnnindonesia.com 2016). Kemudian, diikuti oleh sektor angkutan kereta api sebesar Rp73,90 triliun (26,62 persen), sektor industri logam dasar Rp16,78 triliun (6,04 persen), sektor perumahan, kawasan industri dan perkantoran Rp13,96 triliun (5,03 persen), serta sektor perdagangan sebesar Rp9,32 triliun (3,36 persen). Selain China, BKPM mencatat negara lainnya yang investornya banyak mengajukan izin prinsip ke BKPM adalah Singapura Rp203,89 triliun dan Jepang sebesar Rp100,64 triliun. Kemudian diikuti Malaysia sebesar Rp69,13 triliun, Korea Selatan Rp60,52 triliun, dan Amerika Serikat Rp56,31 triliun (cnnindonesia.com 2016).

Peningkatan investasi China di Indonesia juga terkait dengan dorongan dari pemerintah China terhadap perusahaan BUMN dan perusahaan swasta untuk meningkatkan investasi keluar negeri. Investasi ke luar negeri atau Out Foreign Direct Investment (OFDI/ODI) China telah berkembang sejak tahun 2002, hingga pada tahun 2007-2008 meningkat lebih dari dua kali lipat. Perdana Menteri Wen pada tahun 2011 dalam laporan tahunan kerja pemerintah ke 
Kongres Rakyat Nasional (National People's Congress/ NPC) mendesak atas perlindungan hak-hak luar negeri China dengan menyatakan bahwa:

\footnotetext{
"Kami akan mempercepat penerapan strategi go global, memperbaiki kebijakan pendukung yang relevan, menyederhanakan prosedur pemeriksaan dan persetujuan, dan memberikan bantuan kepada perusahaan dan individu yang memenuhi syarat untuk melakukan investasi di luar negeri. Kami juga akan mendorong perusahaan untuk beroperasi secara internasional, secara aktif, namun tertib. Kami akan memperkuat panduan makro mengenai investasi luar negeri, memperbaiki mekanisme untuk menstimulasi dan melindungi mereka, dan menjaga risiko investasi” (Davies 2013).
}

Kemudian, pada tanggal 7 Maret 2011 Menteri Perdagangan, Chen Deming menyatakan bahwa tahun 2010 rasio ODI: FDI adalah 6:10 dan bahwa rencananya adalah untuk terus mencapai keseimbangan antara ODI dan FDI (yakni rasio 1: 1) dalam waktu sekitar 5-10 tahun (Davies 2013). Angka ODI adalah non-financial ODI sebesar USD 59 miliar, sedangkan angka FDI sekitar USD 100 miliar adalah untuk total FDI. Sehingga pemerintah China akan lebih ambisius untuk melakukan investasi keluar negeri. ODI China sendiri dilakukan pada industri strategis yang sedang berkembang. Industri-industri ini meliputi teknologi informasi generasi berikutnya, konservasi energi, perlindungan lingkungan, energi baru, bioteknologi, manufaktur peralatan kelas atas, material baru dan kendaraan energi baru. Industri-industri ini akan menjadi fokus investasi pemerintah China yang besar. Serta adanya kemungkinan bahwa perusahaan domestik di sektor ini akan sangat didorong untuk menjadi global, baik dengan ekspansi greenfield atau dengan akuisisi perusahaan di tempat lain di dunia

Dengan demikian, pemerintah China melakukan pengurangan jumlah tahapan pemeriksaan dan izin bagi perusahaan yang ingin melakukan proyek investasi di luar negeri. Selain itu, pemerintah juga meringankan bebas administrasi. Perusahan yang melakukan investasi ke luar negeri sebagian besar adalah perusahan milik negara, dan sebagian kecil lainnya merupakan perusahaan swasta. Dimana perusahaan-perusahaan milik negara dapat mengajukan investasi luar negeri mereka tanpa harus menyerahkannya untuk pemeriksaan dan persetujuan. Karena fokus utama strategi go global adalah membangun juara nasional dan ini terutama BUMN, dominasi BUMN cenderung berlanjut. Pada Maret tahun 2011 ambang batas untuk pengujian dan persetujuan proyek investasi luar negeri dalam kategori sumber daya alam meningkat dari USD 30 juta menjadi USD 300 juta, sementara ambang untuk pemeriksaan dan persetujuan kategori lain dari proyek investasi luar negeri meningkat dari USD 10 Juta sampai Rp 100 juta (Davies 2013).

Kebijakan China go global ini sendiri dikelola oleh Ministry of Commerce (MOFCOM) yang sebelumnya adalah Ministry of Foreign Trade and Economic Co-operation (MOFTEC). Kebijakan tersebut mencakup investasi luar negeri, proses perdagangan dan litbang luar negeri, kerjasama sumber daya luar negeri, kontrak teknik asing, dan kerjasama tenaga kerja, termasuk mempekerjakan warga China di luar negeri. Perjanjian yang mencakup FDI luar China dinegosiasikan oleh Departemen Traktat dan Hukum di bawah MOFCOM. Departemen juga menyetujui, memantau dan mengelola perusahaan yang melakukan investasi di luar negeri, tidak termasuk layanan keuangan. Kemudian, merumuskan dan menerapkan standar mengenai kualifikasi perusahaan domestik yang melakukan investasi di luar negeri. Departemen tersebut memonitor FDI di luar China baik dari segi kuantitas maupun kualitas, serta bertanggung jawab untuk menetapkan dan menerapkan sistem statistik pada FDI ke luar negeri dan untuk merumuskan dan menerapkan evaluasi kinerja dan inspeksi tahunan untuk investasi di luar negeri (Davies 2013).

Dengan demikian, investasi China di luar negeri sangat dipantau oleh pemerintah, termasuk kerjasama yang terdapat di dalam perjanjian investasi tersebut. Dimana MOFCOM 
dan kementerian lainnya memiliki peran penting dalam mengembangkan sektor investasi oleh perusahaan China di berbagai wilayah dunia. Selain itu, Departemen Luar Negeri dan Kerjasama Ekonomi juga ditugaskan untuk membimbing, mengatur dan mengkoordinasikan pembangunan bidang kerjasama ekonomi luar negeri. Sehingga pemerintah China mengambil inisiatif dalam mendirikan zona semacam ini di negara lain, di mana perusahaan mereka dapat memperoleh keuntungan dari eksternalitas positif dari pembangunan infrastruktur, publisitas bersama dan sebagainya (Davies 2013).

Bantuan luar negeri China dan kegiatan investasi yang disponsori pemerintah (China's Foreign Aid and Government-Sponsored Investment Activities/FAGIA) seperti di Afrika, Amerika Latin, Timur Tengah, Asia Selatan, Asia Tengah, dan Asia Timur ini menganut delapan prinsip bantuan luar negeri. Delapan prinsip ini bertujuan untuk tidak menerapkan kondisi politik apapun, tidak mencampuri urusan dalam negeri negara-negara penerima dan sepenuhnya menghormati hak mereka untuk secara independen memilih jalan dan model pembangunan mereka sendiri. Prinsip dasar yang dipegang China dalam memberikan bantuan luar negeri adalah rasa saling menghormati, kesetaraan, menjaga janji, saling menguntungkan dan mengharapkan win-win solution (Information Office of the State Council The People's Republic of China 2011).

Bantuan ke luar negeri oleh pihak China merupakan tujuan China untuk mengintegrasikan kepentingan orang-orang China dengan orang-orang dari negara lain, memberikan bantuan sebaik mungkin ke negara-negara berkembang lainnya dalam kerangka kerjasama Selatan-Selatan untuk mendukung dan membantu negara-negara berkembang lainnya, terutama Negara-negara terbelakang (LDCs), untuk mengurangi kemiskinan dan memperbaiki penghidupan. China telah secara pro-aktif mempromosikan pembangunan dan kerjasama internasional dan memainkan peran konstruktif dalam aspek ini. Sementara itu, China menawarkan bantuan asing dalam delapan bentuk yakni proyek lengkap, barang dan bahan, kerjasama teknis, kerjasama pengembangan sumber daya manusia, tim medis dikirim ke luar negeri, bantuan kemanusiaan darurat, program sukarela di luar negeri, dan keringanan utang (Information Office of the State Council The People's Republic of China 2011).

Dalam White Paper China's Foreign Aid pada Juli 2014, bantuan luar negeri China dibedakan berdasarkan sumber keuangan yang terdiri dari tiga jenis yakni:

1. Grant (hibah)

Hibah terutama digunakan untuk membantu negara-negara penerima untuk membangun proyek kesejahteraan sosial kecil atau menengah seperti rumah sakit, sekolah dan rumah dengan biaya rendah, dan mendukung proyek penggalian sumur atau pasokan air, dan proyek menengah dan kecil untuk kesejahteraan sosial lainnya. Selain itu, hibah digunakan dalam proyek-proyek di bidang kerjasama pengembangan sumber daya manusia, kerjasama teknis, bantuan darurat dan bantuan kemanusiaan darurat.

2. Interest-free loan (pinjaman bebas bunga)

Pinjaman bebas bunga terutama digunakan untuk membantu negara penerima membangun fasilitas umum dan meluncurkan proyek untuk memperbaiki penghidupan masyarakat. Jangka waktu pinjaman tersebut biasanya 20 tahun, termasuk lima tahun penggunaan, lima tahun masa tenggang dan sepuluh tahun pembayaran. Saat ini, pinjaman tanpa bunga terutama diberikan kepada negara berkembang dengan kondisi ekonomi yang relatif baik.

3. Concessional loan (pinjaman konsesional)

Pinjaman konsesional digunakan untuk membantu negara-negara penerima melakukan proyek manufaktur dan proyek infrastruktur besar dan menengah dengan manfaat ekonomi dan sosial, atau untuk penyediaan pabrik, mesin dan produk elektronik secara lengkap. Pinjaman konsesional diajukan oleh Bank Ekspor-Impor China di pasar, dan karena bunga pinjaman lebih 
rendah dari suku bunga acuan Bank Rakyat China, perbedaan tersebut dibuat oleh Negara sebagai subsidi finansial. Saat ini, tingkat bunga tahunan pinjaman lunak China antara $2 \%$ dan 3\%, dan jangka waktu pembayaran biasanya 15 sampai 20 tahun (termasuk lima sampai tujuh tahun masa tenggang). Pada akhir tahun 2009, China telah memberikan pinjaman lunak kepada 76 negara asing, yang mendukung 325 proyek, dimana 142 telah selesai dibangun. Dari pinjaman konsesional China, $61 \%$ digunakan untuk membantu negara-negara berkembang untuk membangun infrastruktur transportasi, komunikasi dan ketenagalistrikan, dan 8,9\% digunakan untuk mendukung pengembangan energi dan sumber daya alam seperti minyak dan mineral.

Bantuan luar negeri China telah membantu negara penerima untuk mewujudkan pembangunan ekonomi dan sosial. Dalam White Paper China's Foreign Aid pada Juli 2014 juga dijelaskan bahwa China mengatur hibah, pinjaman tanpa bunga dan konsensi pinjaman secara proporsional untuk membantu negara-negara penerima dengan konstruksi infrastruktur yang sangat dibutuhkan (Information Office of the State Council The People's Republic of China 2014). China sendiri memiliki keunggulannya dalam teknologi, peralatan dan material, dan sumber daya manusia. Sehingga bantuan luar China telah efektif mengurangi biaya investasi untuk proyek-proyek ini namun tetap memastikan kualitas.

Dalam bantuan luar negeri untuk meningkatkan infrastuktur, China membangun berbagai proyek transportasi, termasuk jalan, jembatan, bandara dan pelabuhan. Kemudian untuk meningkatkan kapasitas pasokan energi, China juga membangun stasiun pembangkit listrik tenaga air, pembangkit listrik tenaga panas, transmisi tenaga, transformasi dan jaringan distribusi, dan proyek pengeboran panas bumi. Selain itu, China membantu pembangunan jaringan telekomunikasi kabel optik, situs web e-government, dan pemancar modulasi frekuensi radio dan televisi.

\section{Turnkey Project dan Pelanggaran UU Ketenagakerjaan}

Investasi dan bantuan luar negeri dari China masuk ke Indonesia secara beriringan. Sehingga sulit membedakan antara bantuan luar negeri dan investasi. Hal ini dikarenakan, adanya kepentingan investasi dalam bantuan luar negeri China. Kemudian, berdasarkan turnkey project yang ditandatangani oleh pemerintah Indonesia merupakan kontrak pengerjaan yang secara lengkap. Dalam white paper DPR, turnkey project adalah sebuah model investasi asing yang banyak ditawarkan dan diisyaratkan oleh China kepada negara lain sebagai sistem satu paket. Konsekuensi dari kesepakatan ini ialah mulai dari top management, tenaga ahli, dan tenaga kasar didatangkan dari China.

Dengan demikian, Indonesia menggunakan pinjaman luar negeri China dalam jenis pinjaman konsesional. Dimana Indonesia mendapatkan sejumlah proyek infrastruktur secara lengkap seperti transportasi, dan ketenagalistrikan dan mendukung pengembangan energi dan sumber daya seperti minyak dan mineral. Proyek secara lengkap sendiri yakni China bertanggung jawab atas keseluruhan atau sebagian proses, mulai dari studi, survei, hingga perancangan dan konstruksi, menyediakan semua atau sebagian peralatan dan bahan bangunan, dan mengirim insinyur dan tenaga teknis untuk mengatur dan membimbing konstruksi, instalasi dan produksi percobaan proyek-proyek ini. Setelah sebuah proyek selesai, China menyerahkannya ke Indonesia.

Namun, kesepakatan turnkey project ini sangat bertentangan dengan UU Nomor 13 Tahun 2013 tentang Ketenagakerjaan. Dalam pasal 42 hingga 49 dijelaskan bahwa adanya pembatasan penggunaan TKA guna menjamin kesempatan kerja bagi warga negara Indonesia. Dimana TKA hanya dapat menduduki jabatan yang ditentukan dalam Keputusan Menteri Nomor 173 Tahun 2000. Serta, selama tenaga kerja Indonesia belum mampu melaksanakan 
pekerjaan tersebut Oleh karena itu, TKA yang akan dipekerjakan di Indonesia hanya dalam hubungan kerja untuk jabatan tertentu dan waktu tertentu.

Selain itu, kesepakatan ini juga melanggar Undang-Undang Nomor 25 Tahun 2007 tentang Penanaman Modal yang menyebutkan bahwa perusahaan penanaman modal dalam memenuhi kebutuhan tenaga kerja harus mengutamakan tenaga kerja warga negara Indonesia, dan membatasinya untuk jabatan dan keahlian tertentu, serta mewajibkan perusahaan penanaman modal (baik dalam negeri maupun asing) untuk meningkatkan kompetensi tenaga kerja warga negara Indonesia melalui pelatihan kerja serta alih teknologi. Sehingga kebijakan turnkey project yang dicanangkan oleh pemerintah China tidak sesuai dengan jabatan-jabatan yang telah tercantum dalam Permen. Kemudian, tidak memberikan keutamaan kesempatan kerja bagi warga negara Indonesia dan pelatihan kerja atau alih teknologi yang tidak dijalankan oleh investor.

\section{Penghapusan dan Perubahan Kebijakan}

Guna menciptakan iklim investasi, pemerintah Indonesia melakukan penyederhanaan dalam pengurusan izin investasi di Indonesia. Hal ini tercantum dalam Kebijakan Ekonomi Jilid I pada September 2015 yang terdiri dari tiga langkah yakni yang pertama, Mendorong daya saing industri nasional melalui deregulasi, debirokratisasi, serta penegakan hukum dan kepastian usaha. Kedua adalah mempercepat proyek strategis nasional dengan menghilangkan berbagai hambatan, sumbatan dalam pelaksanaan dan penyelesaian proyek strategis nasional tersebut. Ketiga adalah meningkatkan investasi di sektor properti. Berdasarkan kebijakan ekonomi tersebut, Pemerintah melakukan langkah penyederhanaan izin, memperbaiki prosedur kerja perizinan, memperkuat sinergi, peningkatan kualitas pelayanan, serta menggunakan pelayanan yang berbasis elektronik (Setneg.go.id 2015). Kemudian, Presiden Joko Widodo meminta Badan Koordinasi Penanaman Modal (BKPM) untuk membangun pelayanan terpadu satu pintu (PTSP) atau one stop service dalam perizinan investasi.

Walau demikian, kebijakan PTSP ini telah dimulai sejak masa pemerintahan Presiden Susilo Bambang Yudhoyono pada tahun 2005 dan semakin berkembang setelah disahkannya UU Nomor 25 tahun 2009 tentang Pelayanan Publik. Dengan adanya pelayanan ini, pemohon perizinan tidak perlu mengurus berbagai surat dan dokumen di Kementerian yang berbeda. Namun, pelayanan PTSP ini masih memiliki banyak kendala yang mengikutinya, salah satunya yakni pemerintah kabupaten/kota harus meminta rekomendasi dari pemerintah provinsi hingga pusat. Kebijakan PTSP pada masa Presiden Joko Widodo ini lebih memudahkan investor dalam mendapatkan semua jenis perizinan dengan mendatangi satu Kementerian atau Dinas terkait saja.

Selain itu, pemerintah juga membatalkan ribuan Peraturan Daerah yang dinilai menghambat iklim investasi. Walaupun, permasalahan selanjutnya muncul ketika para kepala daerah menerbitkan SK Gubernur dan SK Bupati baru. Sampai kemudian pemerintah pusat menghimbau pemerintah daerah untuk tidak mengeluarkan kebijakan yang menyulitkan investasi. Sehingga Menteri Perdagangan Enggartiasto Lukita menegaskan bahwa kerumitan perizinan di daerah telah menjadi penghambat investasi di Indonesia selama ini (Liputan6.com 2016). Selanjutnya, pemerintah melakukan review terhadap berbagai peraturan yang multiinterpretative. Pemerintah juga akan mengambil sikap dengan memakai instrument anggaran yakni dana alokasi khusus akan dihapus untuk daerah yang terkait, termasuk mengurangi jumlah dana alokasi umum (DAU). Presiden Joko Widodo mengatakan bahwa: "Kita ini ingin menyederhanakan, ingin menghapus, ingin menghilangkan hambatan-hambatan dalam perizinan dan investasi baik pusat maupun daerah karena kita harus sadar bahwa kita adalah 
Negara Kesatuan Republik Indonesia dan tanggung jawab saya dari pusat sampai daerah itu semua harus diselesaikan" (Setneg.go.id 2017).

Presiden Joko Widodo juga memberlakukan penghapusan syarat bagi TKA bisa berbahasa Indonesia yang tercantum dalam Pasal 26 ayat (1) Pemenkertrans Nomor 12 tahun 2013 dengan dikeluarkannya Permenaker Nomor 16 Tahun 2015 tentang Ketenagakerjaan pada 29 Juni 2015. Hal ini juga ditegaskan oleh Sekretaris Kabinet Pramono Anung yang mengatakan bahwa Presiden telah meminta Menteri Ketenagakerjaan RI untuk menghapus regulasi yang menjadi penghalang untuk direvisi, termasuk penghapusan syarat berbahasa Indonesia (news.viva.co.id 2015). Hal ini bertujuan untuk memberikan kemudahan bagi para TKA yang hendak bekerja di Indonesia. Selain itu, kebijakan ini merupakan keluhan sejumlah investor lokal maupun asing. Dengan demikian, Presiden meyakini dengan melakukan penghapusan sejumlah peraturan akan menarik investasi masuk ke Indonesia.

Kemudian, pada 23 Oktober 2015, pemerintah mengeluarkan Permenaker Nomor 35 Tahun 2015 yang juga menghapus sejumlah kebijakan terkait tenaga kerja asing dalam Permenaker Nomor 16 tahun 2015. Di mana pemerintah telah menghapus Pasal 3 ayat 1 yang menjelaskan bahwa pemberi kerja TKA atau dalam hal ini perusahaan yang mempekerjakan 1 (satu) orang TKA harus dapat menyerap TKI sekurang-kurangnya 10 (sepuluh) orang pada perusahaan. Kemudian, penghapusan dan perubahan dalam Pasal 16 yang berisi mengenai aturan pemberian RPTKA (Rencana Penggunaan Tenaga Kerja Asing untuk pekerjaan bersifat sementara) untuk Pekerjaan yang bersifat sementara. Dimana dengan adanya perubahan tersebut, pemberian RPTKA diberikan pada pembuatan film yang bersifat komersial, untuk melakukan audit, kendali mutu produksi, atau inspeksi pada cabang perusahan di Indonesia untuk jangka waktu lebih dari 1 (satu) bulan. Pekerjaan yang berhubungan dengan pemasangan mesin, elektrikal, layanan purna jual, atau produk dalam masa penjajakan usaha. Sehingga bagi TKA yang bertujuan untuk memberikan pelatihan, mengikuti rapat, memberikan ceramah, melakukan uji coba kemampuan dalam bekerja dan pekerjaan yang sekali selesai tidak perlu memiliki RPTKA.

Selanjutnya, terdapat perubahan pada Pasal 37 terkait penghapusan kewajiban memiliki IMTA bagi TKA yang tidak berdomisili di Indonesia. Serta, penghapusan Pasal 40 ayat (2) Permenaker Nomor 16 tahun 2015 mengatur tentang DKP-TKA yang dibayarkan harus dikonversi ke Rupiah. Penghapusan ayat 2 tersebut bertentangan dengan Undang-Undang Pasal 27 Nomor 7 Tahun 2011 tentang Mata Uang. Di mana dalam Pasal 27 diatur bahwa mata uang Rupiah wajib digunakan dalam tiap transaksi yang memiliki tujuan pembayaran dan penyelesaian kewajiban yang harus dipenuhi dengan uang.

Berbagai penghapusan dan perubahan peraturan ketenagakerjaan memberikan kemudahan bagi investor asing. Dimana para investor tidak perlu mengkhawatirkan wajib Berbahasa Indonesia bagi TKA dan kewajiban memiliki RPTKA dan IMTA bagi TKA yang berdomisili di luar negeri serta melakukan pekerjaan sekali selesai. Selain itu, perusahaan pemberi kerja TKA tidak wajib menyerap sepuluh tenaga kerja lokal dalam merekrut satu TKA. Hal ini menunjukkan bahwa pemerintah Indonesia sangat melonggarkan peraturan terkait TKA guna menarik investor, khususnya asal China. Ketua Komisi IX DPR RI Dede Yusuf, dalam wawancara dengan penulis mengatakan bahwa pelonggaran kebijakan terhadap ketenagakerjaan asing di Indonesia diindikasi merupakan titipan dari investor asal China, mengingat jumlah investasi China meningkat dibanding pada pemerintahan sebelumnya. Selain itu, selama ini investor asing yang telah lama berinvestasi di Indonesia seperti Korea Selatan, Singapura, Amerika Serikat dan sebagainya tidak mempermasalahkan aturan mengenai kewajiban berbahasa Indonesia.

Pada sisi lain, penulis tidak menemukan adanya kesinambungan antara kewajiban Bahasa Indonesia bagi TKA dan tujuan mendorong peningkatan investasi di Indonesia. Hal ini 
dikarenakan sebagian besar negara di dunia memiliki persyaratan khusus bagi tenaga kerja yang hendak bekerja di wilayahnya. Hal ini sesuai dengan prinsip World Trade Organization (WTO) yakni Most-favored-nation (MFN) Treatment-Non Discrimination principles. Dimana anggota WTO harus memperlakukan negara lain secara setara berdasarkan kesepakatan WTO. Sehingga negara tidak dapat membedakan kebijakan antara mitra mereka, mulai dari aktivitas perdagangan barang dan jasa hingga investasi. Namun, dalam keadaan terbatas, negara diperbolehkan melakukan diskriminasi seperti kewajiban menguasai Bahasa negara tersebut. Hal ini tidak melanggar peraturan WTO, dikarenakan kewajiban berbahasa Indonesia bertujuan untuk melindungi pekerja lokal. Di mana sebelumnya, kebijakan ini juga diterapkan merata bagi seluruh pekerja asing yang bekerja di wilayah Indonesia. Selain itu, pemerintah seharusnya konsisten dalam menjalankan perannya untuk mencapai tujuan UU Nomor 24 Tahun 2009 pada Pasal 44 yang menjadikan Bahasa Indonesia sebagai Bahasa Internasional.

Sementara itu, perubahan ketenagakerjaan asing juga berkorelasi dengan perubahan kebijakan terkait pembebasan kewajiban visa bagi 169 negara saat berkunjung ke Indonesia dengan diberlakukannya Peraturan Presiden Nomor 21 Tahun 2016 yang ditandatangani Presiden Joko Widodo pada 2 Maret 2016. Sebelumnya, Bebas Visa Kunjungan diberikan kepada 45 negara berdasarkan Peraturan Presiden Nomor 69 Tahun 2015 sejak 10 Juni 2015. Penerima Bebas Visa Kunjungan dapat keluar dan masuk melalui 124 tempat pemeriksaan imigrasi darat, laut, dan udara. Peraturan ini bertujuan untuk memudahkan akses bagi turis. Hal ini dikarenakan pemerintah Indonesia sedang berfokus pada pembangunan infrastruktur untuk meningkatkan pariwisata Indonesia.

Kebijakan bebas visa ini telah ditawarkan oleh Pemerintah China untuk WNI baik untuk pemegang paspor diplomatik, paspor Dinas, serta paspor biasa. Hal ini ditegaskan oleh Duta Besar China untuk Indonesia Liu Jianchao saat bertemu Wakil Presiden Boediono bahwa China di masa datang akan membebaskan visa bagi warga negara Indonesia yang akan mengunjungi negaranya dengan waktu kurang dari 30 hari (Republika.co.id 2013). Hal ini terkait dengan jumlah wisatawan China yang berkunjung ke Indonesia sebanyak 750 ribu. Serta sebanyak 150 ribu warga China berkunjung ke Indonesia untuk tujuan bisnis.

Terdapat Forum Konsultasi ke-7 bidang Kekonsuleran dan Keimigrasian Indonesia dan China pada 26 November 2013 yang dipimpin oleh Direktur Konsuler Kementerian Luar Negeri RI Tri Tharyat, dan Direktur Konsuler Kementerian Luar Negeri Huang Ping. Dalam pertemuan tersebut adanya pembahasan mengenai fasilitas bebas visa yang akan diberikan oleh China. Namun, Duta Besar RI untuk China merangkap Mongolia Imron Cottan mengatakan bahwa tawaran bebas visa bagi WNI ini perlu dikaji lebih mendalam oleh Kementerian terkait. Setelah dikaji secara matang selanjutnya pemerintah Indonesia memberikan pernyataan kepada pemerintah China (Antaranews.com 2013).

Indonesia sendiri telah memberikan visa on arrival bagi warga negara China yang berkunjung ke Indonesia. Namun, hingga kini negara China belum memberikan fasilitas bebas visa atau visa on arrival bagi warga negara Indonesia. Pada sisi lain, kebijakan bebas visa bagi WNI tercantum dalam draft perjanjian antara pemerintah Indonesia dan China tentang Pemberian Kebijakan Bebas Visa Bagi Pemegang Paspor Biasa (Agreement Between The Government Of The People's Republic Of China And The Government Of The Republic Of Indonesia On Mutual Visa Exemption For Holders Of Ordinary Passports). Kemudian, Indonesia pada 10 Juni 2015 dengan dikeluarkannya Perpres Nomor 69 tahun 2015 terkait pembebasan visa bagi 45 negara yang didalamnya termasuk negara China. Selanjutnya, terjadi peningkatan jumlah negara hingga 169 yang diberikan bebas visa kunjungan ke Indonesia.

Sebaliknya, Pemerintah China sendiri hanya memberikan bebas visa kunjungan tidak lebih dari 15 hari kepada Jepang, Singapura dan Brunei Darussalam (au.china-embassy.org 2013). Bagi negara-negara yang memiliki hubungan diplomatik dengan China, maka 
dibebaskan visa jika sudah berada di Hong Kong atau Makao dan bergabung dengan kelompok turis yang diselenggarakan oleh agen perjalanan, yang terdaftar di Hong Kong atau Macao, untuk kunjungan ke daerah Delta Sungai Mutiara (termasuk Guangzhou, Shenzhen, Zhuhai, Foshan, Dongguan, Zhongshan, Jiangmen, Zhaoqing dan Huizhou) dan masa tinggalnya tidak lebih dari 6 hari (au.china-embassy.org 2013).

Namun demikian, Indonesia tidak termasuk ke dalam daftar negara yang memiliki hubungan diplomatik. Sehingga Indonesia hanya mendapatkan bebas visa jika menggunakan biro perjalanan internasional yang terdaftar di Hainan. Kunjungan ini juga dibatasi selama tidak lebih dari 15 hari. Berbagai peraturan ini menunjukkan bahwa China sangat berhati-hati dalam memberikan kebijakan bebas visa bagi negara lain. Hal ini bertolak belakang dengan pemerintah Indonesia yang memberlakukan bebas visa bagi 169 negara tanpa melihat asas manfaat.

Diketahui bahwa sebelumnya pemerintah menambah jumlah negara-negara yang berhak mendapatkan bebas visa. Hal ini menunjukkan bahwa pemerintah kurang matang dalam memberlakukan kebijakan. Selain itu, negara-negara yang mendapatkan bebas visa diantaranya menimbulkan pertanyaan mengenai alasan pemerintah dalam memberikan kepada negaranegara tersebut seperti Haiti yang berada di Kepulauan Karibia. Dimana untuk berwisata ke Indonesia para turis asal Haiti harus menempuh 30 jam perjalanan, dan sebagian besar warga negaranya tidak bisa berbahasa Inggris.

Kebijakan bebas visa ini diberlakukan untuk meningkatkan perekonomian dan jumlah wisatawan mancanegara untuk berkunjung ke Indonesia. Kebijakan ini juga menggunakan asas timbal balik dan manfaat. Dimana pemerintah menargetkan jumlah kunjungan wisatawan negara sebanyak 20 juta orang pada tahun 2019. Berdasarkan data pada Gambar tersebut diketahui bahwa jumlah Wisatawan yang paling tinggi pada tahun 2016 berasal dari negara China dengan jumlah 1,438 juta orang. Kemudian diikuti Singapura dan Australia, dengan masing-masing sebanyak 1,423 juta dan 1,18 juta orang.

Kemudian pada Januari 2017, jumlah kunjungan wisatawan mancanegara ke Indonesia mengalami kenaikan 26,58 persen menjadi 1,03 juta kunjungan jika dibandingkan Januari tahun 2016. Sebanyak 200.197 orang diantaranya adalah wisatawan asal China, diikuti Singapura 116.791 kunjungan. Sehingga wisatawan China paling banyak datang ke Indonesia. Kebijakan bebas visa ini berlaku di 124 tempat pemeriksaan darat, udara dan laut. Salah satu tempat pemeriksaan yang mengalami kenaikan tertinggi yakni di Bandara Sam Ratulangi, Sulawesi Utara sebesar 100,89 persen. Kenaikan ini disebabkan adanya penerbangan langsung dari Bandara Sam Ratulangi ke beberapa kota di China. Sementara di Bandara Soekarno-Hatta, pada Januari 2017 juga mengalami kenaikan 23,28 persen menjadi 189,2 ribu orang dan Bandara Hang Nadim, Batam juga naik sebesar 19,14 persen dengan jumlah penumpang sebanyak 129,7 ribu orang jika dibandingkan dengan 2016.

Ketua Panitia Kerja evaluasi Kebijakan Bebas Visa Komisi I DPR RI Hanafi Rais menjelaskan bahwa pemberlakukan kebijakan bebas visa ini secara keseluruhan belum berpengaruh besar terhadap peningkatan kunjungan wisatawan mancanegara (Tempo.co 2017). Dengan demikian Panja Komisi I DPR memberikan rekomendasi untuk melakukan evaluasi terhadap kebijakan tersebut. Terdapat tiga poin utama rekomendasi tersebut yakni pertama, evaluasi dilakukan terhadap negara dengan visa tetapi jumlah kunjungannya tidak naik secara signifikan. Sehingga negara-negara ini disarankan untuk diberikan kebijakan visa on arrival. Kemudian, rekomendasi kedua yakni evaluasi terhadap negara-negara yang tidak menghormati kedaulatan negara Indonesia. Ketiga, bebas visa tidak perlu diberikan kepada negara yang warga negaranya melakukan banyak pelanggaran peraturan keimigrasian.

Rekomendasi yang diberikan oleh Panja Komisi I dikarenakan asas timbal balik dan manfaat yang dimiliki, sehingga negara-negara yang tidak memberikan manfaat perlu dihapus 
dari daftar bebas visa. Kemudian negara-negara yang memiliki GDP kecil dengan mayoritas masyarakatnya tidak meyakinkan untuk melakukan wisata ke Indonesia perlu dikaji ulang. Dengan demikian kebijakan bebas visa ini dapat lebih bermanfaat bagi Indonesia, dengan melakukan seleksi yang lebih mendalam. Di mana manfaat ini dapat dilihat dari peningkatan belanja yang diterima oleh masyarakat. Ketika peningkatan jumlah wisatawan diikuti dengan peningkatan belanja rumah tangga maka memberikan dampak yang nyata pada masyarakat.

\section{Peningkatan Tenaga Kerja Asing Ilegal Asal China di Indonesia}

Penghapusan dan perubahan kebijakan ketenagakerjaan asing yang diterapkan pada masa pemerintahan Presiden Joko Widodo diikuti dengan peningkatan jumlah tenaga kerja asing ilegal di Indonesia. Jumlah TKA di Indonesia pada tahun 2016 mencapai 74.183 orang. Dimana China menjadi negara pemasok TKA tertinggi dengan jumlah 21.271 orang. Adapun data statistik IMTA yang dikeluarkan oleh Kementerian Ketenagakerjaan RI pada Januari-April 2017 mencapai 10.904 orang. Hal ini menunjukkan tingginya minat pengusaha menggunakan TKA khususnya asal China untuk bekerja di Indonesia. Dengan demikian, jumlah TKA asal China pada triwulan I 2017 ini akan terus terjadi peningkatan.

Tabel 1. Daftar Izin Mempekerjakan TKA (IMTA) Tahun 2013-April 2017

\begin{tabular}{|l|l|l|l|l|l|l|}
\hline No & Negara Asal TKA & $\mathbf{2 0 1 3}$ & $\mathbf{2 0 1 4}$ & $\mathbf{2 0 1 5}$ & $\mathbf{2 0 1 6}$ & April 2017 \\
\hline 1 & China & 14.371 & 16.328 & 17.515 & 21.271 & 10,904 \\
\hline 2 & Jepang & 11.081 & 10.838 & 12.653 & 12.490 & 7,007 \\
\hline 3 & Korea Selatan & 9.075 & 8.172 & 7.590 & 8.424 & 3,433 \\
\hline 4 & India & 6.047 & 4.981 & 5.900 & 5.059 & 2,375 \\
\hline 5 & Malaysia & 4.962 & 4.022 & 4.305 & 4.138 & 1,705 \\
\hline 6 & Amerika Serikat & 2.167 & 2.658 & 3.731 & 2.812 & 1,190 \\
\hline 7 & Thailand & 1.841 & 1.002 & 3.557 & 2.394 & 1,218 \\
\hline 8 & Australia & 3.376 & 2.664 & 3.069 & 2.483 & 1,074 \\
\hline 9 & Philippina & 2.601 & 2.670 & 3.126 & 3.428 & 1,280 \\
\hline 10 & Inggris & 2.631 & 2.227 & 2.531 & 2.252 & 983 \\
\hline 11 & Singapura & 1.814 & 1.835 & 1.245 & 1.748 & 790 \\
\hline 12 & Negara Lainnya & 8.961 & 11.365 & 3.803 & 7.684 & 6,067 \\
\hline & Total & $\mathbf{6 8 . 9 5 7}$ & $\mathbf{6 8 . 7 6 2}$ & $\mathbf{6 9 . 0 2 5}$ & $\mathbf{7 4 . 1 8 3}$ & $\mathbf{3 8 , 0 2 6}$ \\
\hline
\end{tabular}

Sumber: Kementerian Ketenagakerjaan RI, data diolah kembali oleh Penulis

Berdasarkan Grafik 1. data tentang daftar izin mempekerjakan TKA (IMTA), diketahui bahwa jumlah TKA yang bekerja pada sektor Perdagangan dan Jasa cukup tinggi. Pada tahun 2014, jumlah TKA dalam sektor ini mencapai 36.702 orang, kemudian pada tahun 2015 meningkat 40.491 orang. Hingga pada tahun 2016 terjadi peningkatan dari tahun sebelumnya yakni 51.695 orang. Kemudian, sektor kedua yang dipenuhi oleh TKA yakni sektor Industri, di mana pada tahun 2016 berjumlah 20.584 orang. Meski terjadi penurunan ditahun sebelumnya yang berjumlah 26.317 orang. 


\section{Grafik 1. Daftar Izin Mempekerjakan TKA Berdasarkan Sektor}

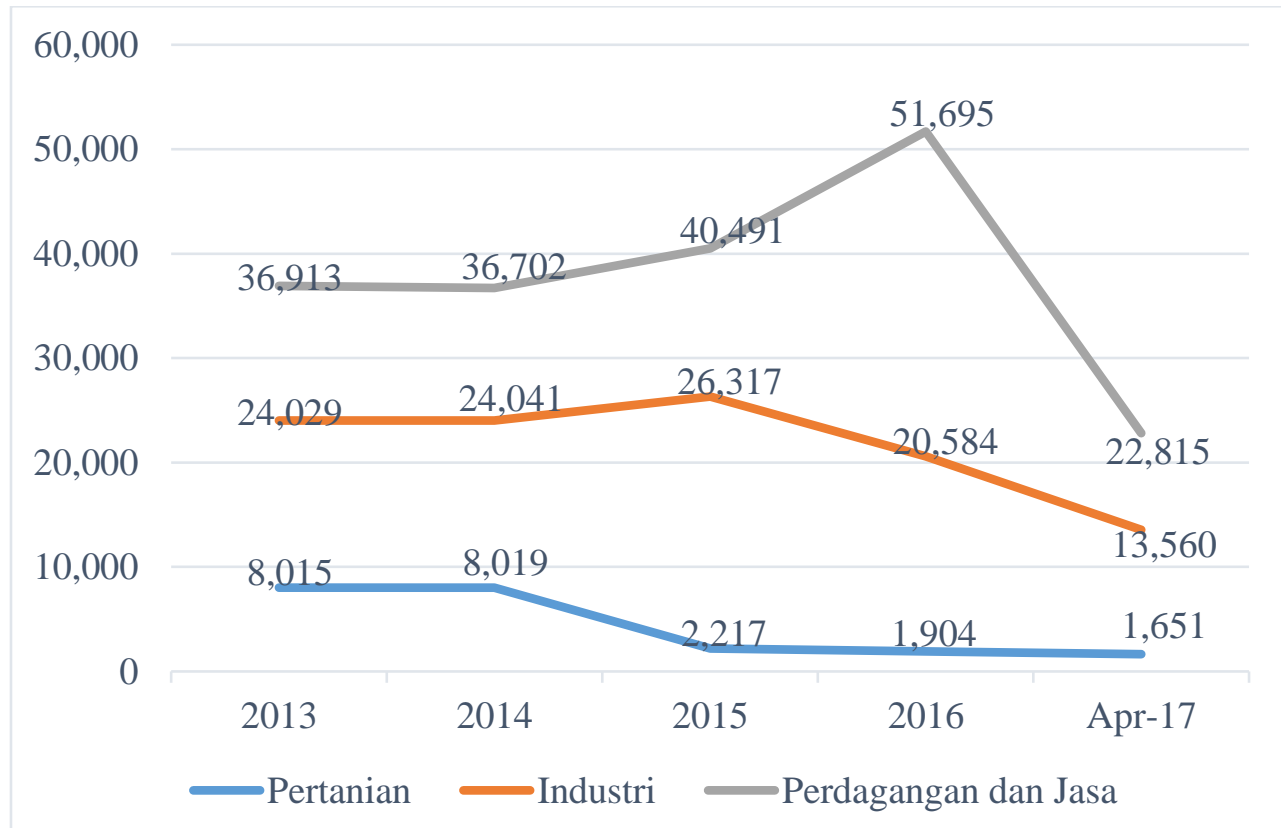

Sumber: Kementerian Ketenagakerjaan RI, data diolah kembali oleh Penulis

Kenaikan jumlah TKA asal China di Indonesia di berbagai sektor diikuti dengan peningkatan jumlah kasus TKA ilegal. Meski hingga saat ini secara kuantitatif belum adanya data yang akurat terkait jumlah TKA ilegal asal China di Indonesia, namun dominasi kasus TKA ilegal asal China menjadi sebuah fakta yang tidak bisa dibantahkan oleh pemerintah. Dalam 75 kasus yang penulis kumpulkan dari 19 Provinsi di Indonesia melalui berbagai sumber, diketahui adanya 70 kasus TKA asal China yang memiliki pola bekerja yang sama di Indonesia, serta 5 kasus lainnya terkait cybercrime dan prostitusi.

Dimana, dalam kasus-kasus tersebut diketahui adanya sebuah pola TKA China di berbagai daerah yang tidak memiliki IMTA. Sehingga para TKA masuk terlebih dahulu menggunakan visa turis untuk bekerja di Indonesia. Kegiatan ini juga diiringi dengan proses pengurusan IMTA di Kementerian terkait. Tentu, hal ini tidak sesuai dengan peraturan tenaga kerja yang berlaku, bahwa tenaga kerja yang bekerja di Indonesia harus memiliki IMTA sebelum bekerja yang diajukan oleh pihak sponsor. Setelah mendapatkan izin, tenaga kerja asing tersebut dapat bekerja di Indonesia.

Pola pelanggaran TKA asal China di Indonesia ini juga akibat pemalsuan dokumen dengan mencantumkan jabatan tertentu di perusahaan tempat mereka bekerja, namun faktanya bekerja sebagai pekerja kasar. Dalam wawancara dengan penulis, Ketua Komisi IX DPR RI, Dede Yusuf mengatakan bahwa:

"Jadi harus dibedakan antara tukang pasir dan operator mesin pasir. Para TKA asal China levelnya adalah operator mesin pasir. Sehingga kalau mesin-mesin yang digunakan berasal dari China dan menggunakan Bahasa China, dalam klausul kebutuhannya perusahaan perlu menggunakan tenaga kerja untuk menjadi operator mesin. Maka, level para TKA ini diatas pekerja kasar orang Indonesia. Tetapi jenis pekerjaan mereka adalah tetap pekerja kasar. Perbedaannya adalah para pekerja China menggunakan alat yang tidak dimengerti oleh pekerja Indonesia. Maka para TKA asal China ini seolah-olah bukan pekerja kasar, atau biasanya disebut dengan teknisi. Selain itu, perusahaan melarang pekerja lokal untuk mempelajari mesin tersebut sehingga tidak terjadi transfer of technology". 
Berdasarkan beberapa kasus yang dikumpulkan tersebut, para TKA ilegal bekerja di industri, pertambangan dan pembangunan pembangkit listrik, jalan tol, bendungan dan sebagainya berada pada jabatan teknisi. Hal ini sejalan dengan peningkatan penggunaan TKA dalam bidang perdagangan dan jasa dalam Grafik 1. Selain itu, Anggota Komisi III DPR RI Didik Mukrianto menjelaskan kepada penulis bahwa dalam kunjungan lapangan yang dilakukan bersama-sama oleh Komisi III dan Komisi IX juga ditemukan TKA yang legal. Namun mereka bekerja sebagai buruh bangunan, pekerja kasar, dan sebagainya yang datang ke Indonesia melalui proyek yang ditanganinya.

Sementara itu, Direktur Pengendalian TKA, Wisnu Pramono menanggapi maraknya TKA ilegal dengan membedakan 2 jenis TKA yang bekerja di Indonesia yaitu TKA yang sifatnya sementara dan sifatnya tetap. Pekerja China yang bekerja di proyek infrastruktur merupakan pekerja sementara, di mana para pekerja bertugas untuk memasang mesin, turbin dan sebagainya. Hal ini juga dikarenakan pinjaman dari China yang memberikan paket termasuk tenaga kerjanya. Dan investasi China di Indonesia berjumlah ratusan milyar atau sekitar $70 \%$, termasuk investasi dari Singapura. Karena sebagian pengusaha melakukan investasi melewati perusahaan yang berada di Singapura.

Selain itu, Wisnu Pramono menegaskan jumlah investasi yang tinggi dan keberadaan TKA China sebagai pekerja kasar ini merupakan hal yang wajar. Hal ini dikarenakan para TKA hanya bekerja di Indonesia dalam waktu beberapa bulan, tidak dalam waktu tetap. Kewajiban berbahasa Indonesia juga tidak diperlukan karena memakan waktu yang lama, tidak sebanding dengan waktu kerja TKA yang hanya sekitar 4-5 bulan. Kemudian, proyek infrastruktur ini selanjutnya juga akan dipenuhi oleh para pekerja lokal, sehingga masyarakat diharapkan tidak perlu khawatir terkait isu TKA ilegal asal China yang menyerbu Indonesia. Namun demikian, nyatanya hal ini telah melanggar UU Ketenagakerjaan dan UU penanaman modal yang berisikan tentang keharusan mengutamakan kesempatan kerja bagi warga negara Indonesia untuk bekerja di perusahaan penanam modal. Terlebih, adanya kasus TKA asal China yang memiliki dokumen lengkap namun bekerja sebagai buruh kasar di proyek pemerintah. Serta, perbedaan upah yang diterima oleh TKA dan TKI pada proyek dan pekerjaan yang sama. Hal ini tentu menimbulkan kecemburuan sosial di masyarakat Indonesia.

Berdasarkan Grafik 2. diketahui bahwa data izin mempekerjakan TKA pada tahun 2013Apr 2017 yang dikeluarkan oleh Kementerian Ketenagakerjaan RI, pekerja dengan jabatan teknisi mengalami peningkatan. Pada tahun 2014 hanya berjumlah 3.433 orang, di tahun 2015 meningkat sebanyak 8.913 orang. Kemudian di tahun 2016 sebanyak 10.614 orang. Namun demikian, jumlah ini tidak bisa menjadi data yang tetap. Di mana tingginya jumlah kasus TKA ilegal yang menggunakan jabatan komisaris, manager dan professional guna bekerja sebagai pekerja kasar di sebagian besar proyek di Indonesia. 


\section{Grafik 2 Daftar Izin Mempekerjakan TKA Berdasarkan Jabatan TKA}

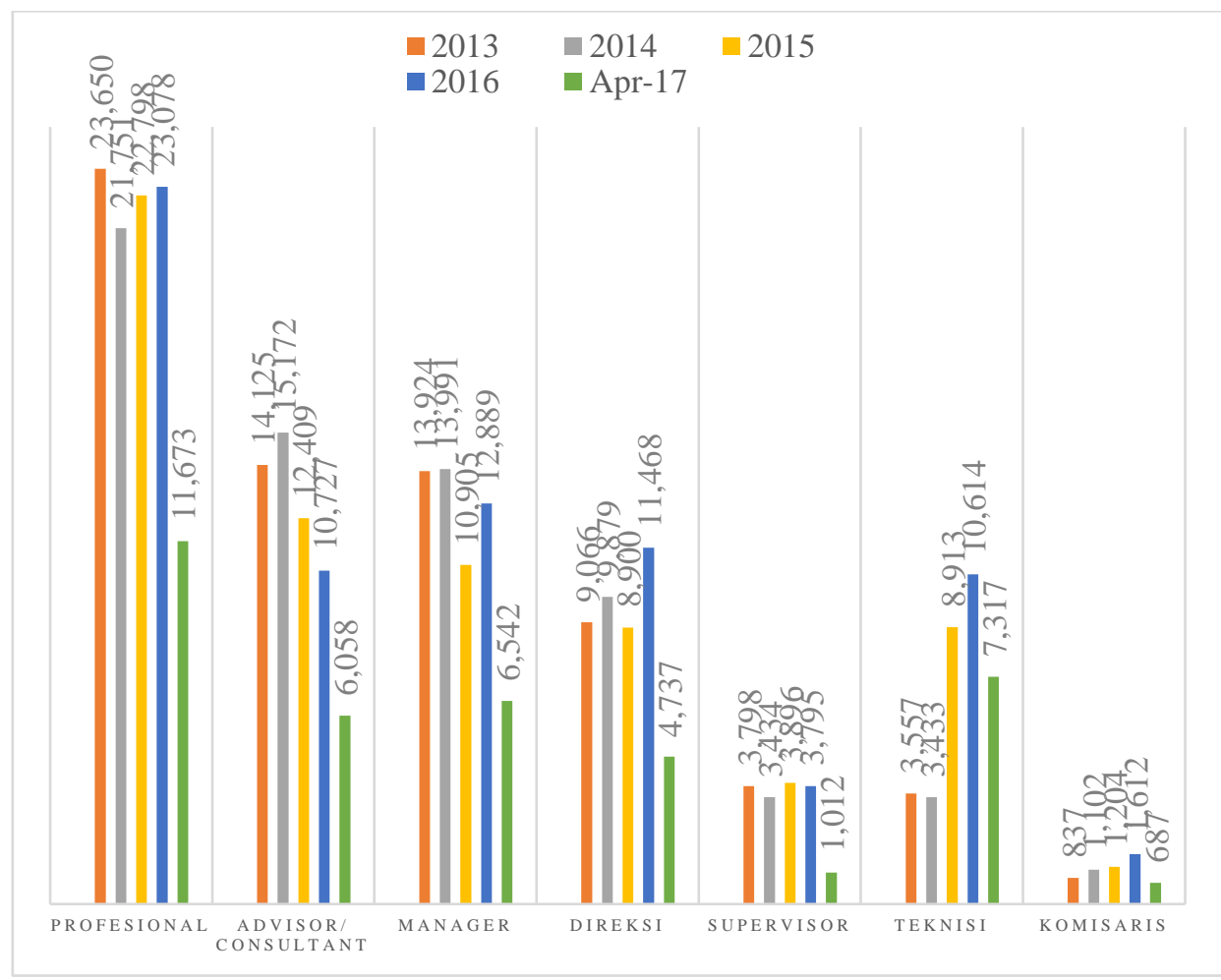

Sumber: Kementerian Ketenagakerjaan RI, data diolah kembali oleh Penulis

Peningkatan TKA ilegal ini diindikasi akibat dari Turnkey project yang ditandatangani oleh pemerintah sebagai deal guna memperoleh pinjaman yang tinggi dari China. Dede Yusuf menegaskan bahwa sejumlah pinjaman yang diberikan China menggunakan deal dengan memberikan pembangunan-pembangunan infrastuktur kepada China. Di Indonesia sendiri menggunakan sistem tender dalam melakukan pembangunan infrastruktur. Namun demikian, perusahaan asal China memiliki ciri pembangunan infrastuktur dengan waktu yang cepat, harga yang murah, dan kualitas yang baik. Kualitas yang baik ini dapat dipastikan dengan menggunakan barang, alat-alat dan membawa tenaga kerja asal China. Kemudian, para pekerja ini menggunakan sistem kontrak selama 4-5 bulan secara bergantian. Setelah pekerja berada di pembangunan Indonesia yang sesuai dengan bidang keterampilannya selama 3-4 bulan, maka mereka akan dipindahkan ke negara lain lagi. Biaya pemindahan pekerja ini menggunakan biaya investasi yang diberikan.

Lebih lanjut, kontrak pekerja selama 3-4 bulan ini sangat menguntungkan negara China karena memberikan pekerjaan kepada pengangguran mereka. Sistem penggajian para pekerja ini juga dalam sebagian kasus ditemukan sekitar 3 kali lipat gaji pekerja lokal. Di mana pekerja lokal dibayar 2 juta rupiah perbulan, maka TKA asal China mendapatkan gaji sekitar 6 juta rupiah perbulan. Namun demikian, pembayaran yang diberikan kepada pekerja hanya sepertiga gaji, sedangkan duapertiga gajinya dikirimkan kepada keluarga pekerja di negara asal. Maka duapertiga gaji tersebut menjadi devisa bagi negara China.

Sementara itu, sistem kontrak pekerja asal China selama 3-4 bulan ini menyebabkan berbagai instansi terkait tidak bisa menemukan sejumlah TKA yang tidak berizin. Dede Yusuf menjelaskan bahwa:

“... Kami telah melakukan sidak di berbagai perusahaan banyak ditemukan TKA yang tidak memiliki izin, misalnya di satu perusahaan terdapat 100 pekerja yang berizin dan 300 pekerja 


\begin{abstract}
lainnya tidak berizin. Kalau ditanya kepada perusahaan kenapa tidak berizin? Jawabannya adalah sedang dalam pengurusan. Pengurusan ini seharusnya diurus terlebih dahulu, kemudian pekerja datang. Tetapi sekarang bertolakbelakang, dimana pekerja datang dahulu, dan izinnya di proses. Ketika izinnya telah selesai diproses, kontrak kerjanya sudah habis. Sehingga para TKA ini sulit untuk ditangkap."
\end{abstract}

Proses ini dapat dianggap sebagai permainan perusahaan sendiri untuk melindungi tenaga kerjanya. Di mana dalam sebagian kasus yang penulis temukan, ketika berbagai instansi melakukan sidak namun tidak ditemukan TKA ilegal dengan jumlah ratusan pekerja. Pada sisi lain, berdasarkan laporan masyarakat terdapat ratusan pekerja asing asal China yang bekerja di salah satu perusahaan tersebut. Hal serupa disampaikan oleh Didik Mukrianto yang mengatakan bahwa bagaimanapun juga disetiap brand yang disebut ilegal terdapat niat dan komitmen korporasi yang sudah tidak baik. Tentu dengan niat dan semangat yang tidak baik tersebut, perusahaan akan terus menyembunyikan apa yang ada di perusahaan mereka dengan cara masing-masing.

Namun demikian, pemerintah Indonesia dalam hal ini telah melakukan deal pinjaman utang dan pembangunan infrastruktur. Sehingga laporan berbagai kasus terkait tenaga kerja ilegal tidak ditindak secara serius. Serta adanya indikasi pejabat daerah ikut serta dalam melindungi TKA asal China di berbagai daerah. Hal ini ditegaskan oleh Wakil Ketua Komisi I, Tubagus Hasanuddin yang mengatakan bahwa adanya indikasi keterlibatan pejabat daerah dalam TKA ilegal ini, namun masih dikaji lebih dalam. Selain itu, Dede Yusuf juga menjelaskan bahwa ketika kepala daerah atau bupati mendapatkan investasi yang besar dari perusahaan asing. Maka investasi yang masuk pasti akan dijaga ketat oleh pejabat daerah. Hal ini dikarenakan kalau investasi tersebut diganggu maka perusahaan tersebut akan pindah ke daerah lain dan daerah tersebut kehilangan dana investasi.

Berdasarkan hasil pemeriksaan penggunaan TKA yang dilakukan oleh Kementerian Tenaga Kerja pusat dan daerah terhadap 69 perusahaan pada tahun 2016. Ditemukan bahwa terdapat jumlah pelanggaran (pusat) yang dilakukan oleh 691 TKA. Dimana terdapat 587 orang tanpa IMTA dan 104 TKA melakukan penyalahgunaan jabatan. Kemudian di Kementerian daerah, ditemukan 633 TKA melakukan pelanggaran dengan 207 TKA tanpa IMTA dan 426 TKA melakukan penyalahgunaan jabatan. Dengan demikian, jumlah TKA yang tidak memiliki IMTA yakni 794 orang dan 530 orang melakukan penyalahgunaan jabatan pada tahun 2016.

Peningkatan jumlah pelanggaran keimigrasian yang dilakukan oleh orang asing di Indonesia semakin bertambah akibat penghapusan kebijakan ketenagakerjaan asing dan diikuti kebijakan bebas visa. Dalam Grafik 3. Ditjen Keimigrasian telah melakukan tindakan administratif terhadap TKA ilegal pada tahun 2015 sebanyak 3764 kasus, dan terjadi peningkatan pada tahun 2016 dengan total 7787 orang. Pada periode Januari-November 2016, orang asing asal China berada pada tingkat tertinggi dengan jumlah 1837 kasus. Diikuti oleh negara Afghanistan (655 kasus), Bangladesh (389), Malaysia (245) dan Vietnam (213). Somalia (198), Irak (183), Filipina (182), Iran (181), dan India (180). 
Grafik 3. Tindakan Administratif Keimigrasian

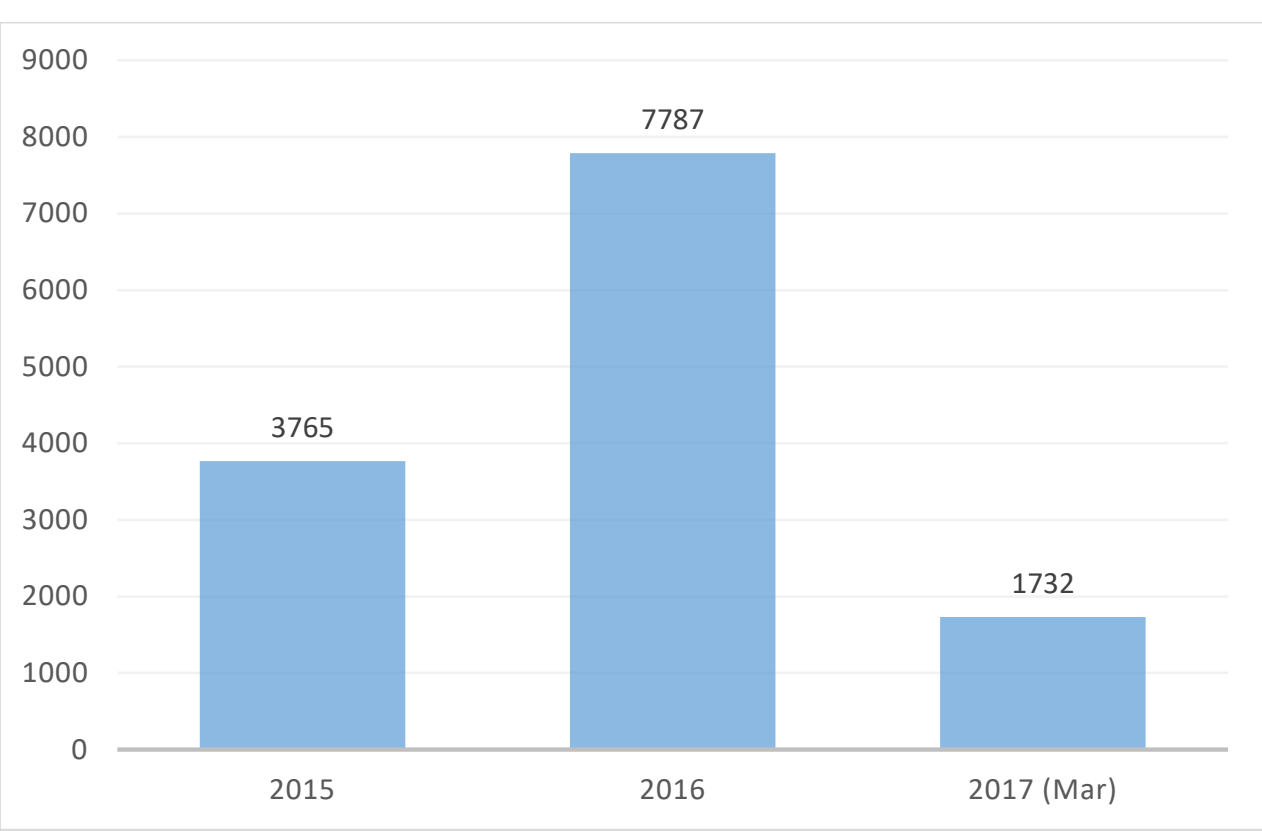

Sumber: Direktorat Jenderal Imigrasi, data diolah kembali oleh Penulis

Peningkatan TKA ilegal asal China juga berdampak pada peningkatan kasus kriminal lainnya yakni dalam kasus narkoba, negara China menduduki peringkat kedua setelah Nigeria dengan 8 kasus di tahun 2015 dan 15 kasus. Sementara itu, selama tahun 2016, Dirjen Imigrasi melakukan penindakan proses dengan Pro Justisia yakni China 126, Nigeria 134, Bangladesh 27, India 19, Indonesia 18, Thailand 17, Maroko 11, Korea selatan 11, Malaysia 10, Myanmar 9.

Pada 31 Juli 2017, Menteri Hukum dan HAM Yasonna H Laoly mengambil langkah tegas terhadap warga negara asal China dan Taiwan yang berhasil ditangkap oleh Tim Satgasus Polri dan Kepolisian China dari tiga lokasi berbeda, yakni Bali, Surabaya dan Jakarta (Cnnindonesia.com 2017). Para WNA yang ditangkap karena kejahatan siber itu akan dideportasi. Selain itu, Yasonna mengaku tidak percaya jika ratusan warga negara asal negeri tirai bambu itu tidak memiliki izin saat masuk ke wilayah Indonesia.

Namun demikian pernyataan Menteri Yasonna Laoly menimbulkan pertanyaan bagi penulis, kasus TKA yang tidak memiliki izin lengkap telah ada selama beberapa tahun ini. Penyataan tidak percaya ini, menunjukkan bahwa pemerintah tidak serius terdapat kasus TKA ilegal. Menurut Didik Mukrianto, fakta di lapangan tidak bisa dibantah oleh Menteri Laoly. Di mana banyak turis yang menggunakan bebas visa masuk Indonesia tetapi menyalahgunakan visa. Kemudian pemerintah tidak bisa mendeteksi kegiatan apa yang dilakukan turis selama di Indonesia. Sehingga tidak mengejutkan banyak warga asing yang menyalahgunakan visa. Terlebih, banyaknya pintu tidak resmi yang bisa masuki oleh pekerja ilegal. Kepercayaan dan lembaga negara termasuk Kementerian Hukum dan HAM bukan berdasarkan keyakinan yang dibangun oleh pemerintah sendiri tetapi bagaimana informasi dan fakta di lapangan. Kemudian melakukan konfirmasi terhadap informasi tersebut.

Lebih lanjut, Komisioner Ombudsman Laode Ida mengungkapkan bahwa banyaknya jumlah TKA yang ilegal terkait dengan upaya Pemerintah Indonesia yang saat ini sedang menggerakkan iklim investasi yang positif bagi investor asing (Kompas.com, 2017f). Sehingga banyak investor yang datang ke Indonesia, namun hal ini dimanfaatkan oleh para investor untuk 
mendapatkan keuntungan besar dengan mempekerjakan tenaga kerja dengan upah rendah. Selain itu, Indonesia memberikan bebas visa kepada sebagian negara yang tidak memberikan bebas visa serupa kepada Indonesia, termasuk China.

Banyaknya dampak yang merugikan bagi Indonesia, menunjukkan bahwa peraturan bebas visa bagi 169 negara harus ditinjau ulang. Kemudian, Pemerintah perlu lebih memberikan kesempatan kerja bagi tenaga kerja Indonesia. Dimana perusahaan yang menggunakan investasi asing harus tetap menciptakan lapangan pekerjaan bagi tenaga kerja Indonesia. Serta, diberlakukannya kembali peraturan menteri ketenagakerjaan terkait tata cara penggunaan tenaga kerja asing untuk memperketat warga negara asing bekerja di Indonesia. Sehingga tenaga kerja asing illegal yang masuk ke Indonesia dapat diminimalisir.

\section{Kesimpulan dan Rekomendasi}

Peningkatan investasi China di Indonesia membawa pengaruh terhadap penanganan Ketenagakerjaan Asing pada masa pemerintahan Joko Widodo. Hal ini tampak dalam berbagai perubahan regulasi dalam pengaturan tenaga kerja asing yang dianggap sebagai hambatan dalam menarik investasi luar negeri. Dalam hal ini pemerintah melakukan deregulasi peraturan perundang-undangan, baik pusat maupun daerah yang dapat menghambat pekerja asing untuk masuk ke Indonesia.

Perubahan peraturan ketenagakerjaan asing juga dilakukan beriringan dengan kebijakan bebas visa kunjungan yang diberlakukan pada 10 Maret 2016 bagi 169 negara. Peraturan ini bertujuan untuk meningkatkan hubungan negara Indonesia dengan negara lain, serta meningkatkan jumlah wisatawan dari mancanegara. Namun dalam pelaksanaannya, kebijakan bebas visa menjadi celah bagi masuknya TKA ilegal ke Indonesia.

Sementara itu, berbagai perubahan dan penghapusan peraturan ketenagakerjaan asing juga diikuti dengan kasus TKA ilegal di berbagai daerah. Dalam berbagai kasus yang penulis kumpulkan menunjukkan adanya sebuah pola pelanggaran yang dilakukan oleh TKA asal China. Di mana mereka tidak memiliki KITAS dan IMTA, mencantumkan jabatan tertentu namun pada kenyataannya hanya sebagai pekerja kasar, overstay serta adanya TKA yang hanya memiliki visa turis untuk bekerja di Indonesia. Dalam periode Januari-November 2016, orang asing asal China berada pada tingkat tertinggi dengan jumlah 1837 kasus. Hal ini menunjukkan ketidaktegasan pihak imigrasi untuk menindak atau mencegah datangnya TKA ilegal dalam pemeriksaan keimigrasian.

Selain itu, penulis juga menemukan adanya keganjilan dari penanganan keimigrasian dan kepolisian. Di mana ketika Tim Pengawasan orang asing bersama anggota DPR dan pejabat terkait lainnya melakukan inspeksi mendadak ke perusahaan yang diindikasi terdapat ratusan TKA ilegal, berulang kali perusahaan tersebut tidak ditemukan TKA yang ilegal. Sedangkan, berdasarkan laporan dari masyarakat pada hari-hari biasanya terdapat ratusan TKA asal China di perusahaan tersebut. Hal ini sangat ganjil bagi penulis. Adanya indikasi keterlibatan perusahaan dan instansi terkait lainnya serta pejabat daerah tersebut yang menyembunyikan keberadaan TKA. Terlebih, adanya laporan masyarakat sekitar perusahaan yang mengatakan bahwa pintu masuk perusahaan dijaga oleh aparat kepolisian. 


\section{DAFTAR PUSTAKA}

\section{Wawancara}

Effendi, Dede Yusuf Macan, Ketua Komisi IX Dewan Perwakilan Rakyat Republik Indonesia (DPR RI) dari Fraksi Partai Demokrat, wawancara dilaksanakan pada Selasa, 18 Juli 2017, di Hotel Ayana Midplaza, Jakarta.

Hasanuddin, TB, Wakil Ketua Komisi I DPR RI dari Fraksi Partai Demokrasi Indonesia Perjuangan, wawancara dilaksanakan pada Jum'at, 26 Juli 2017, di Ruang Kerja Wakil Ketua Komisi 1, Gedung Nusantara 1, Kompleks DPR RI, Senayan, Jakarta.

Lan, Thung Ju, Peneliti Senior tentang Studi China Lembaga Ilmu Pengetahuan Indonesia (LIPI), wawancara dilaksanakan pada Jum'at, 25 November 2016, di Kantor Peneliti, Lantai 9 Gedung LIPI, Jakarta.

Mukrianto, Didik, Anggota Komisi III DPR RI dari Fraksi Partai Demokrat, wawancara dilaksanakan pada Selasa 1 Agustus 2017, di Ruang Perpustakaan Fraksi Partai Demokrat, Gedung Nusantara 1, Kompleks DPR RI, Senayan, Jakarta.

Pramono, Wisnu, Direktur Pengendalian Penggunaan Tenaga Kerja Asing, Kementerian Tenaga Kerja (Kemenaker) RI, wawancara dilaksanakan pada Jum'at, 20 Juli 2017, di Kantor Kementerian Tenaga Kerja RI, Jakarta.

Sampurno, Agung, Kepala Bagian Hubungan Masyarakat Direktorat Jenderal Imigrasi, Kementerian Hukum dan Hak Asasi Manusia (Kemenkumham) RI, wawancara dilaksanakan pada Jum'at, 13 Juli 2017, di Kantor Direktorat Jenderal Imigrasi, Jakarta.

\section{Peraturan dan Undang-Undang}

Undang-Undang Nomor 25 tahun 1997 tentang Ketenagakerjaan Undang-Undang Nomor 13 Tahun 2003 tentang Ketenagakerjaan Undang-Undang Nomor 25 Tahun 2007 tentang Penanaman Modal

Undang-Undang Nomor 24 Tahun 2009 tentang Bendera, Bahasa, dan Lambang Negara, serta Lagu Kebangsaan

Undang-Undang Nomor 7 Tahun 2011 tentang Mata Uang

Peraturan Presiden Nomor 69 tahun 2015 tentang Bebas Visa Kunjungan

Peraturan Presiden Nomor 21 Tahun 2016 tentang Bebas Visa Kunjungan

Keputusan Menteri Nomor 173 Tahun 2000 Jangka Waktu Izin Mempekerjakan Tenaga Kerja Warga Negara Asing Pendatang.

Permenkertrans Nomor 12 Tahun 2013 tata Cara Penggunaan Tenaga Kerja Asing

Permenaker Nomor 35 Tahun 2015 tentang Perubahan Atas Peraturan Menteri Ketenagakerjaan Nomor 16 Tahun 2015 tentang Tata Cara Penggunaan Tenaga Kerja Asing

Peraturan Presiden Nomor 69 tahun 2015 tentang Bebas Visa Kunjungan

Peraturan Presiden Nomor 104 Tahun 2015 tentang Perubahan Atas Peraturan

Presiden Nomor 69 tahun 2011 tentang Bebas Visa Kunjungan

\section{Dokumen Negara}

Information Office of the State Council The People's Republic of China. 2011. "White Paper on China's Foreign Aid (2011)." Beijing.

—. 2014. "White Paper on China’s Foreign Aid (2014).” Vol. 10. Beijing.

\section{Website Resmi Lembaga Pemerintahan}


au.china-embassy.org. (2013). Visa-free Entry into Mainland China. Retrieved May 23, 2017, from http://au.china-embassy.org/eng/ls/vfc/t1038742.htm

Setneg.go.id. 2015. "Gerakkan Ekonomi, Presiden Jokowi Luncurkan Paket Kebijakan Tahap I September 2015." Setneg.go.id. http://setkab.go.id/gerakkan-ekonomi-presidenjokowi-luncurkan-paket-kebijakan-tahap-i-september-2015/.

. 2017. "Presiden Sikapi Keputusan MK Batalkan Kewenangan Mendagri Cabut Perda." Setneg.go.id.

https://www.setneg.go.id/index.php?option=com_content\&task=view\&id=13631\&Ite mid $=55$.

\section{Working Paper}

Davies, Ken. 2013. "China Investment Policy: An Update." 1. Paris. doi:http://dx.doi.org/10.1787/5k46911hmvbt-en OECD.

\section{Artikel Media Online}

Afriyadi, Achmad Dwi. 2016. "Jurus Pemerintah Hilangkan Hambatan Investasi Di Daerah." liputan6.com, October 13. http://bisnis.liputan6.com/read/2625295/jurus-pemerintahhilangkan-hambatan-investasi-di-daerah.

Republika.co.id. 2013. "Cina Akan Bebaskan Visa Untuk WNI." February 14. http://nasional.republika.co.id/berita/nasional/politik/14/02/13/n0xdth-cina-akanbebaskan-visa-untuk-wni.

Setyawan, Feri Agus. 2017. "Yasonna Segera Deportasi Ratusan WNA China Pelaku Cyber Crime." Cnnindonesia.com, July 31. https://www.cnnindonesia.com/nasional/20170731125612-12-231427/yasonna-segeradeportasi-ratusan-wna-china-pelaku-cyber-crime/.

Siswoyo, Harry et al. News.viva.co.id. 2015. “'Bebasnya' Tenaga Kerja Asing Kini Di Indonesia." News.Viva.Co.Id, August 26. http://fokus.news.viva.co.id/news/read/665589-bebasnya-tenaga-kerja-asing-kini-diindonesia.

Supriadi, Agust. 2016. "BKPM: Pemodal China Dominasi Rencana Investasi 2015." Cnnindonesia.com, April 1. http://www.cnnindonesia.com/ekonomi/2016010415084192-102045/bkpm-pemodal-china-dominasi-rencana-investasi-2015/.

Utami, Rini. 2013. "China Tawarkan Bebas Visa Untuk WNI." Antaranews.com, November 29. http://www.antaranews.com/berita/407326/china-tawarkan-bebas-visa-untuk-wni.

Tempo.co. 2017. “Kebijakan Bebas Visa Dinilai Belum Tingkatkan Jumlah Turis.” April 19. https://m.tempo.co/read/news/2017/04/19/090867365/kebijakan-bebas-visa-dinilaibelum-tingkatkan-jumlah-turis. 